\title{
紡鍾形細胞型有棘細胞癌
}

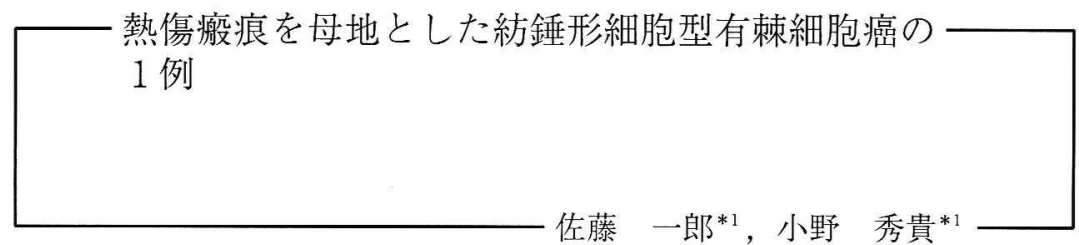

\section{A case of spindle cell squamous cell carcinoma on the burn scar}

Ichiro SATO ${ }^{* 1}$, Hideki ONO ${ }^{* 1}$

*1 Department of Dermatology, Odawara Municipal Hospital

We reported a case of spindle cell squamous cell carcinoma.

The patient was a 73-year-old man who developed an ulcerated nodule, $2.8 \times 2.0 \mathrm{~cm}$ in size, on the burn scar of the head. Histologically, the tumor was composed of disorderly arranged atypical spindle cells, and mitotic figures were often found. Immunohistological studies showed positive reaction of these cells for vimentin and CAM5.2. [Skin Cancer (Japan) $2001 ; 16: 251-254]$

Key words : Squamous cell carcinoma, Spindle cell, Burn scar

\section{はじめに}

熱傷㓔痕を母地とした有棘細胞癌の中には， 紡鍾形細胞が錯綜して間葉系腫瘍様の所見を呈 するものがある。今回我々はそのような紡錘形 細胞型有棘細胞癌の 1 例を経験したので, 若干 の考察を加えて報告する。

\section{症例}

患 者: 73 歳女性

主 訴：左側頭部の結節

初 診: 1996 年 6 月 12 日

既往歴，家族歴：特記すべきことなし。
現病歴：3 歳時に左側頭部に熱傷を受け，73 歳時（1995 年）に㓔痕部に腫瘤が出現し，潰瘍 を伴い徐々に増大した。1996 年 6 月 12 日，当 科を紹介受診した。

初診時現症：左側頭部に $12 \times 10 \mathrm{~cm}$ の熱傷㓔 痕を認め，そのほぼ中央部に $2.8 \times 2 \mathrm{~cm}$ の不整 形腫瘤を認めた（図 1 ）。

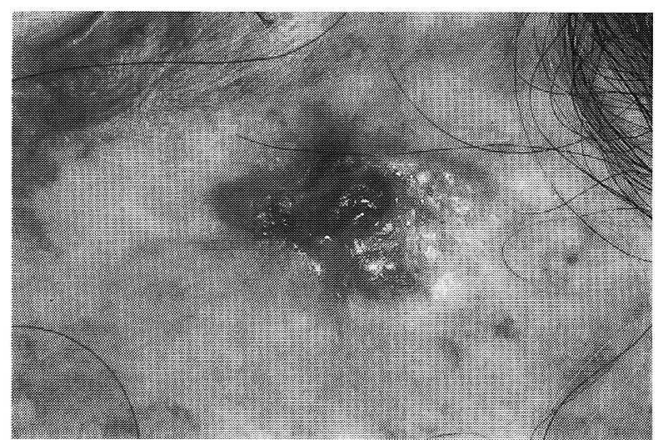

図 1. 初診時臨床像 


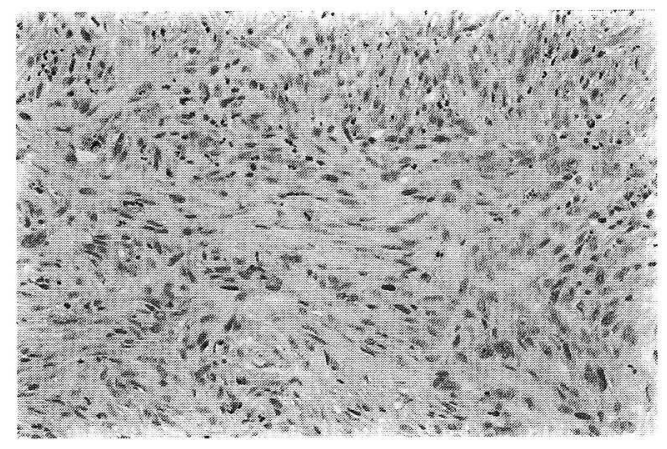

図 2. 生検組織所見 (H.E. 染色)
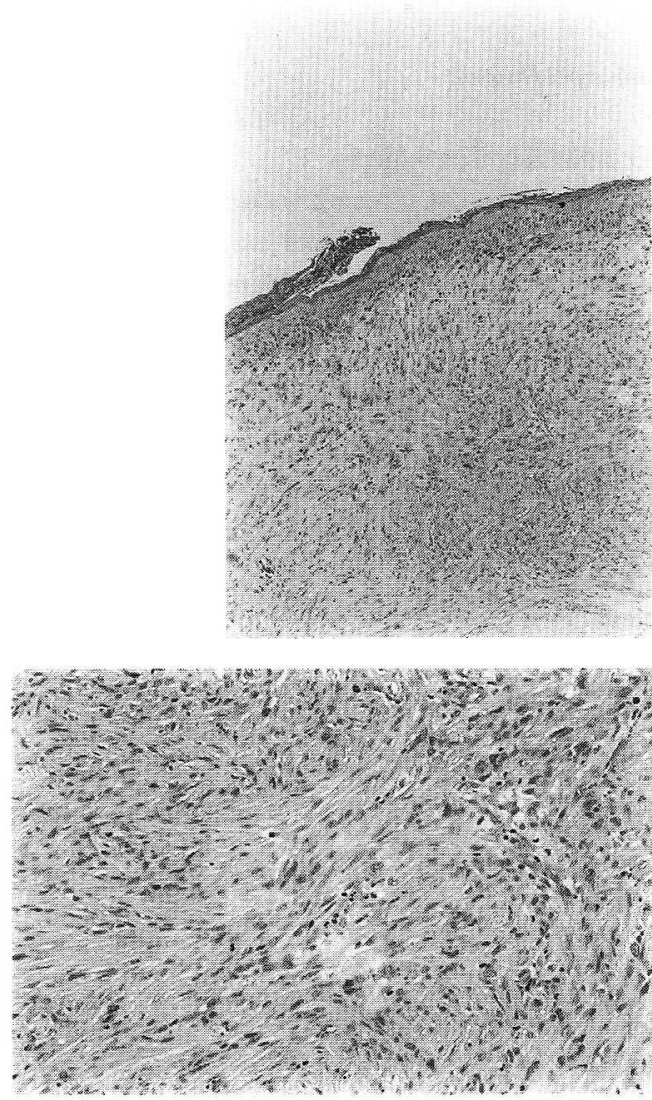

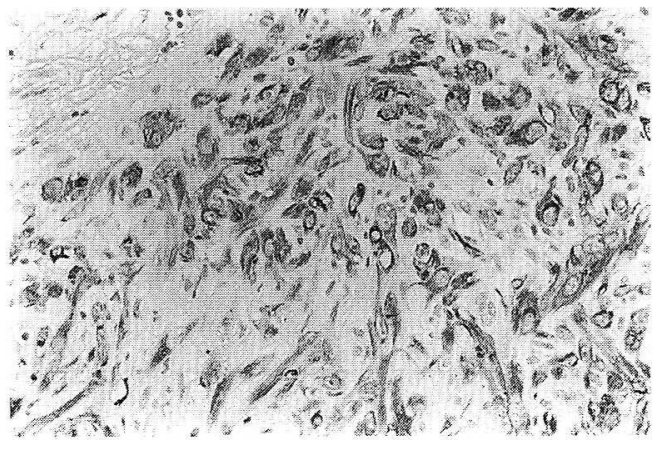

図 3.ビメンチン染色像

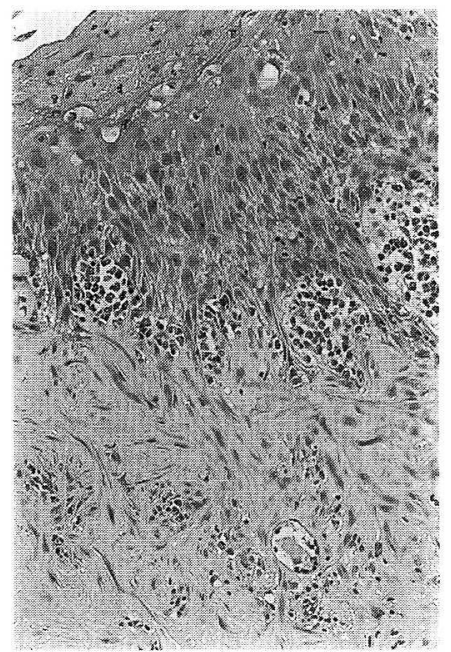

\begin{tabular}{l|l}
$\mathrm{a}$ & $\mathrm{b}$ \\
\hline $\mathrm{c}$ &
\end{tabular}

図 4. 切除標本組織所見 (H.E. 染色)
臨床検査所見：特記すべきことなし。

熱傷瘷痕を母地とした有棘細胞癌を疑い，6

月 17 日, 皮膚生検を行った。

生検標本病理組織所見：腫瘍組織は真皮全層 に認められ，紡錘形の腫瘍細胞が錯綜していた (図 2 )。熱傷瘏痕部に生じた紡錘形細胞型有棘 細胞癌（spindle cell squamous cell carcinoma） を疑ったが，免疫染色ではビメンチン陽性で (図 3), atypical fibroxanthoma (AFX), 悪性 線維性組織球症 (malignant fibrous histiocytoma）等の間葉系腫瘍も考えられた。

7 月 15 日当科入院し, 7 月 16 日腫瘍切除扝 
よび植皮術を行った。

切除標本病理組織学的所見: HE 染色では, 腫瘍塊を真皮上層から下層まで認めた（図 4a)。 表皮には異型細胞，核分裂像が散見された。一 部表皮から真皮にかけて連続的に腫瘍細胞浸潤 が認められた（図4b）。真皮において腫瘍細胞は 胞巣を形成せずびまん性に拡大し, 線維芽細胞 様の紡錘形細胞が様々な方向に錯綜していた (図 4c)。

免疫染色では，単層上皮型ケラチン（ケラチ ン 8,18 ）を染める CAM5.2 は紡錘形細胞の一 部で陽性，表皮型ケラチン（ケラチン 1) を染 める 34 B4 は陰性であった。ビメンチンは一 部で陽性，S-100 蛋白，CD34 は陰性であった。

経 過：自験例は HE 染色像で腫瘍組織が錯 綜する紡錘形細胞からなり，表皮から連続的に 腫瘍細胞浸潤がみられたこと, 免疫染色でビメ ンチンと単層上皮型ケラチンが同時に陽性だっ たことから，熱傷㓔痕部に生じた紡錘形細胞型 有棘細胞癌と診断した。

退院後，外来にて経過観察中であるが，現在 のところ患者に再発兆候はみられていない。

\section{考按}

熱傷瘏痕部を母地として悪性腫瘍が発生した 例は数多く報告されているが，多くは有棘細胞 由来の熱傷瘕痕癌である。しかし熱傷痏痕癌だ けではなく悪性線維性組織球症, 悪性黒色腫 ${ }^{1)}$, 基底細胞上皮腫 ${ }^{2)}$, 脂肪肉腫 ${ }^{3)}$, 外毛根鞘癌 ${ }^{4)}$ といった種々の悪性腫瘍も報告されており，そ れらとの鑑別が必要なことがある。

自験例は HE 染色では肉腫様の組織像を呈 し, 免疫染色でビメンチン陽性であった。ビメ ンチンは本来線維芽細胞，血管内皮細胞などの 間葉系細胞に広く分布し，間葉系腫瘍のマー カーとして用いられるものであり, 自験例が悪 性線維性組織球症等の間葉形悪性腫瘍であるこ とも否定できなかった。しかし上皮系腫瘍にお いても分化度が低い場合にビメンチンが発現す
ることがあり ${ }^{5)}$, Smith らは表皮細胞が形態的, 機能的に間葉系細胞に化生 (metaplasia) した 場合, ビメンチン陽性になると推測している ${ }^{6)}$ 。

また，自験例は腫瘍組織で $34 \beta$ B 4 が陰性, CAM5.2 が陽性であり，表皮型ケラチンではな く単層上皮型ケラチンが発現していた。ケラチ ンは，その分化によって（1）表皮型，（2）特 殊型，（3）単層上皮型，（4）全上皮型に大別 される7)。一般に有棘細胞癌におけるケラチン の発現について，高分化のものは正常上皮と同 様に ${ }^{8)}$ ，表皮型ケラチンを認識する抗体によっ て染色されるが，低分化となるにつれ表皮型ケ ラチンは発現しなくなり, 腫瘍細胞の一部が単 層上皮型ケラチンを認識する抗体で染色される ようになる ${ }^{9)}$ 。

自験例は低分化型の有棘細胞癌であったた め,ビメンチンおよび単層上皮型ケラチンが陽 性になったものと思われた。

紡錘形細胞型有棘細胞癌の進展形態は, 個々 の腫瘍細胞が大部分紡錘形をとり，表皮からの 連続性や細胞間橋に乏しく，真皮に非連続的に 浸潤している点で通常の有棘細胞癌と大きく異 なる。組織学的悪性度は Grade IVに相当し, 形 態的に未分化である。熱傷痏痕部に生じやすい といわれるが，その理由は明らかではない。

自験例が組織学的に紡錘形細胞型となったの は，個々の腫瘍細胞が病変部に適応した結果と も考えられた。すなわち病変部の真皮全層には 線維組織が密に増生しており, 通常の有棘細胞 癌のように腫瘍組織が表皮から胞巣をつくりな がら連続的に進展することが困難であった。そ のため腫瘍細胞が細胞間橋を解消し，紡錘形を とりつつ線維細胞間に浸潤したものと思われ た。

最後に予後についてであるが，自験例は切除 標本が断端陰性であり, 術後 4 年以上経過した 現在も再発兆候はない。しかし本例と同じくビ メンチン陽性の紡錘形細胞型有棘細胞癌につい て予後不良例 ${ }^{10)}$ が報告されており, 今後の注意 深い follow up が必要と思われた。 


\section{文献}

1) Alconchel, M.D., Olivares, C., Alvarez, R. : Squamous cell carcinoma, malignant melanoma and malignant fibrous histiocytoma arising in burn scars. Br. J. Dermatol., 137 : 793-798, 1997.

2) Koga, Y., Sawada, Y. : Basal cell carcinoma developing on a burn scar. Burns, 23:75-77, 1997.

3 ) Nishimoto, S., Matsushita, T., Matsumoto, K., et al. : A rare case of burn scar malignancy. Burns, 22 : 497-499, 1996.

4) Ko, T., Tada, H., Hatoko, M., et al. : Trichilemmal carcinoma developing in a burn scar. J. dermatol., $23: 463-468,1996$.

$5)$ Lane, E.B., Hogan, B.L.M., Kurkinen, M., et al. : Coexpression of vimentin and cytokeratin in parietal endoderm cells of early embryo. Nature, 303: 701-704, 1983.

6) Smith, K.J., Skelton, H.G., et al. : Spindle cell neoplasms coexpressing cytokeratin and vimentin(metaplastic squamous cell carcinoma). J. Cutan. Pathol., 19:286-293, 1992.

7）北島康雄 : 中間系フィラメントの基礎と腫瘍診 断。臨床皮虐, 43(3):217-225, 1989.

8）渡辺晋一：上皮系皮䖉腫瘍におけるケラチン発現 の特徵. 帝京医学雑誌, 18(5): 1-9, 1995.

9）市川栄子, 渡辺晋一, 大塚藤男：皮虐有棘細胞癌 に扔けるサイトケラチン発現の免疫組織化学的検 討．日皮会誌，103(8)：1043-1052, 1993.

10）烟康樹, 秋山真志, 山田晴義, 他: 多彩な病理組 織像を呈した熱傷痏痕癌の 1 例. 臨床皮虐, 48(12) :1127-1131, 1994. 